\title{
Surface-enhanced Raman spectroscopy of blood serum based on gold nanoparticles for tumor stages detection and histologic grades classification of oral squamous cell carcinoma [corrigendum]
}

\author{
Xue L, Yan B, Li Y, Tan Y,Luo X, Wang M. Int JNanomedicine. \\ 2018;13:4977-4986.
}

On page 4985, in the Acknowledgment section, the grant number of National Natural Science Foundation of China was incorrectly listed. It should be as follows:

This study was supported by the National Natural Science Foundation of China (grant no 81502584). reviewed journal focusing on the application of nanotechnology in diagnostics, therapeutics, and drug delivery systems throughout the biomedical field. This journal is indexed on PubMed Central, MedLine, CAS, SciSearch $\AA$, Current Contents $\AA /$ Clinical Medicine,

Journal Citation Reports/Science Edition, EMBase, Scopus and the Elsevier Bibliographic databases. The manuscript management system is completely online and includes a very quick and fair peer-review system, which is all easy to use. Visit http://www.dovepress.com/ testimonials.php to read real quotes from published authors. 